\title{
Relationship Between Health Perception and Life Satisfaction in Individuals Who are Member of Recreative Fitness Center
}

\author{
Hakan Salim ÇAĞLAYAN ${ }^{1}$, Nazlı Deniz ÖZ², Abdil ARI ${ }^{1}$ \\ ${ }^{1}$ Selcuk University, Sport Sciences Faculty, Sport Management,Konya, Turkey \\ ${ }^{2}$ Selcuk University, Sport Sciences Faculty, Receration Departmant, Konya, Turkey \\ Address Correspondence to N.D. ÖZ, e-mail: denizyilmaz@selcuk.edu.tr
}

\begin{abstract}
The aim of this study was to compare the health perception and life satisfaction levels of the individuals doing recreational sports according to various demographic variables and to determine the relationship.

This study was conducted on the basis of survey model; Individuals attending recreational fitness centers in Konya participated on a voluntary basis. "Health Perception Scale" which was developed by Diamond et al. (2007) and adapted to Turkish by Kadıŏlu and Yıldız; and "Life Satisfaction Scale" which was developed by Diener et al. and adapted to Turkish by Köker (1991) were used. SPSS 20 package program was used to analyze the data. In the evaluation of the data, complementary statistical methods like standard deviation (sd) frequency (f) percentage (\%) average (M) and since normal distribution conditions were not met Kruskal Wallis Test and Mann-Whitney U test, which are non-parametric tests, were used. Spearman Correlation coefficient test was used to reveal the relationship between them. Results were evaluated at 0.05 significance level.

As a result of the study, when the health perception scale and life satisfaction scale were compared according to the variables of gender, age and educational status, statistically significant differences were found and it was found that the relationship between life satisfaction and health perception scale had low positive correlation levels with each other. In this context, health perception and life satisfaction can be evaluated as factors affecting each other.
\end{abstract}

Key words: Health Perception, Life Satisfaction, Recreation

\section{INTRODUCTION}

Being healthy is one of the fundamental rights of humans. Today's health care policies, which are based on the protection, maintenance and development of this right, focus on individuals taking responsibility for their own health and gaining behaviors that improve their health (1).

The health benefits of physical activity are also listed as being good for stress-related disorders and paving the way for individuals to think healthily (4).

In addition to the aim of competition, the idea of preserving health is included in the sport context and people are invited to do sports with this idea. This invitation is particularly popular in developed countries and a wide range of people are engaged in various sporting events. With slogans like lifelong sports, sports for healthy living, recreational sports, fitness (physical fitness), aerobics, jogging and so on and the activities of various sports clubs it is tried to increase the number of people doing sports (17).
According to health belief model; perception of health affects health behaviors and health responsibility. Therefore, health perception is directly related to the process of health promotion aiming at gaining and maintaining healthy living behaviors (6).

Youth and adulthood ages are known as the most dynamic period for the individual and society. During these ages, individuals prefer fitness centers, where they can do sports at all times (10). In parallel with this, health perceptions take shape in these ages. It is easier to acquire lifestyle behaviors such as healthy eating, exercise, effective communication and stress coping methods that need to be developed throughout life compared to older individuals. Lifestyle behaviors have a significant effect on individuals' academic achievement, physiological and psychological health $(5,20)$. 
As the importance of physical activity is understood, there is also an increase in the number and density of the members of the fitness centers that provide the modern community with the opportunity of physical activity (13).

Today's modern human has always understood that the sportive activities that she/he is going to do for now are a way of life and they aim to start and continue the sport. (7).

Health is the mainstay of life; meeting the physical, spiritual and social needs of people; increasing the welfare of the society and developing awareness of health perception in individuals in our developing country will be the most fundamental element. Life satisfaction emerged with health awareness and behavior will give the individual the chance to adapt to society and subjective well-being.

\section{METHOD}

This study was conducted on the basis of survey model; Individuals attending recreational fitness centers in Konya participated on a voluntary basis. Turkish reliability and validity tests of five likert type Health Perception Scale which was developed by Diamond et al. (9) and originally in in English was conducted in 2012 by Kadıoglu and Yild1z (14). There are four sub-dimensions titled "Control Center", "Self-awareness", "Precision" and "Importance of Health".

Life satisfaction scale which was developed by Diener et al. (11) and adapted to Turkish by Köker (16) was used to determine life satisfaction levels of the participants. The answers were rated in a 5-point likert style scale ( 1 = definitely not expressing me, 5 = definitely expressing me).

\section{Analysis of data}

SPSS 20 package program was used to analyze the data. In the evaluation of the data, complementary statistical methods like standard deviation (sd) frequency (f) percentage (\%) average (M) and since normal distribution conditions were not met Kruskal Wallis Test and Mann-Whitney U test, which are non-parametric tests, were used. Bonferroni correction from Post-Hoc tests was used to find out which groups caused this difference when there was a difference between the groups. Results were evaluated at 0.05 significance level.

RESULTS

\begin{tabular}{|c|c|c|c|}
\hline & & $\mathbf{N}$ & $\%$ \\
\hline \multirow[t]{2}{*}{ Gender } & Woman & 95 & 49,5 \\
\hline & Man & 97 & 50,5 \\
\hline \multirow[t]{5}{*}{ Age } & 21 age and under & 40 & 20,8 \\
\hline & $22-24$ age & 45 & 23,4 \\
\hline & $25-28$ age & 36 & 18,8 \\
\hline & 29-32 age & 36 & 18,8 \\
\hline & 33 age and above & 35 & 18,2 \\
\hline \multirow[t]{3}{*}{ Education } & Elementary & 27 & 14,1 \\
\hline & High school and equivalent & 95 & 49,5 \\
\hline & Graduate & 70 & 36,5 \\
\hline \multirow[t]{3}{*}{ Monthly Income } & $2000 \mathrm{tl}$ and under & 47 & 24,5 \\
\hline & $2001-3000 \mathrm{tl}$ & 89 & 46,4 \\
\hline & $3001 \mathrm{tl}$ and above & 56 & 29,2 \\
\hline TOTAL & & 192 & 100 \\
\hline
\end{tabular}

Table 2. Results of participants' perception of health and life satisfaction levels according to gender variable

\begin{tabular}{|c|c|c|c|c|c|c|c|c|c|c|c|}
\hline \multirow[b]{3}{*}{ Gender } & \multirow[b]{3}{*}{$\mathrm{n}$} & \multicolumn{8}{|c|}{ Perception of Health Scale } & \multirow{2}{*}{\multicolumn{2}{|c|}{ Life Satisfaction Scale }} \\
\hline & & \multicolumn{2}{|c|}{ Control Center } & \multicolumn{2}{|c|}{$\begin{array}{l}\text { Importance of } \\
\text { Health }\end{array}$} & \multicolumn{2}{|c|}{ Precision } & \multicolumn{2}{|c|}{$\begin{array}{l}\text { Self- } \\
\text { awareness }\end{array}$} & & \\
\hline & & $X$ & Ss & $\bar{x}$ & Ss & $X$ & Ss & $x$ & Ss & $X$ & Ss \\
\hline Woman & 95 & 2,36 & 0,61 & 2,31 & 0,72 & 2,52 & 0,68 & 2,63 & 0,78 & 2,91 & 0,48 \\
\hline Man & 97 & 2,47 & 0,60 & 2,52 & 0,63 & 2,84 & 0,52 & 2,66 & 0,66 & 3,22 & 0,45 \\
\hline \multicolumn{2}{|c|}{$\mathbf{z}$} & \multicolumn{2}{|c|}{$-1,233$} & \multicolumn{2}{|c|}{$-1,608$} & \multicolumn{2}{|c|}{$-3,499$} & \multicolumn{2}{|c|}{$-0,539$} & \multicolumn{2}{|c|}{$-5,035$} \\
\hline \multicolumn{2}{|c|}{$\mathrm{p}$} & \multicolumn{2}{|c|}{0,218} & \multicolumn{2}{|c|}{0,108} & \multicolumn{2}{|c|}{$0,000^{* *}$} & \multicolumn{2}{|c|}{0,590} & \multicolumn{2}{|c|}{$0,000^{* *}$} \\
\hline
\end{tabular}

As can be seen in Table 2, a statistically significant difference was found in favor of male participants in the subdimension of health perception scale and life satisfaction scale of individuals doing recreational sports according to gender variable $(\mathrm{p}<0.01)$. 
Table 3. Findings of health perception and life satisfaction levels of participants according to age variable

\begin{tabular}{|c|c|c|c|c|c|c|c|c|c|c|c|c|}
\hline \multirow[b]{3}{*}{ Age } & & \multirow[b]{3}{*}{$\mathrm{n}$} & \multicolumn{8}{|c|}{ Perception of Health Scale } & \multirow{2}{*}{\multicolumn{2}{|c|}{$\begin{array}{l}\text { Life } \\
\text { Satisfaction } \\
\text { Scale }\end{array}$}} \\
\hline & & & \multicolumn{2}{|c|}{$\begin{array}{l}\text { Control } \\
\text { Center }\end{array}$} & \multicolumn{2}{|c|}{$\begin{array}{l}\text { Importance of } \\
\text { Health }\end{array}$} & \multicolumn{2}{|c|}{ Precision } & \multicolumn{2}{|c|}{$\begin{array}{l}\text { Self- } \\
\text { awareness }\end{array}$} & & \\
\hline & & & $x$ & Ss & $X$ & Ss & $x$ & Ss & $x$ & Ss & $x$ & Ss \\
\hline A & 21 age and under & 40 & 2,35 & 0,58 & 2,37 & 0,72 & 2,83 & 0,53 & 2,70 & 0,74 & 3,02 & 0,42 \\
\hline B & 22-24 age & 45 & 2,53 & 0,62 & 2,52 & 0,69 & 2,91 & 0,54 & 2,82 & 0,76 & 3,11 & 0,53 \\
\hline $\mathrm{C}$ & $25-28$ age & 36 & 2,50 & 0,52 & 2,66 & 0,60 & 2,58 & 0,61 & 2,86 & 0,71 & 3,04 & 0,58 \\
\hline D & 29-32 age & 36 & 2,30 & 0,64 & 2,21 & 0,72 & 2,61 & 0,68 & 2,37 & 0,62 & 2,99 & 0,45 \\
\hline $\bar{E}$ & 33 age and above & 35 & 2,38 & 0,66 & 2,31 & 0,60 & 2,38 & 0,65 & 2,41 & 0,64 & 3,16 & 0,44 \\
\hline \multicolumn{3}{|c|}{$X^{2}$} & \multicolumn{2}{|c|}{3,933} & \multicolumn{2}{|c|}{10,601} & \multicolumn{2}{|c|}{18,097} & \multicolumn{2}{|c|}{15,276} & \multicolumn{2}{|c|}{3,788} \\
\hline \multirow{2}{*}{\multicolumn{2}{|c|}{$p$}} & & \multicolumn{2}{|c|}{0,415} & \multicolumn{2}{|c|}{$0,031^{*}$} & \multicolumn{2}{|c|}{$0,001^{* * *}$} & \multicolumn{2}{|c|}{$0,004^{* *}$} & \multicolumn{2}{|c|}{0,435} \\
\hline & & & & & \multicolumn{2}{|c|}{$\begin{array}{c}\mathrm{D}<\mathrm{B}, \mathrm{C} \\
\mathrm{F}<\mathrm{C}\end{array}$} & \multicolumn{2}{|c|}{$\mathrm{D}<\mathrm{A}, \mathrm{B}$} & \multicolumn{2}{|c|}{$\begin{array}{c}\mathrm{D}<\mathrm{A}, \mathrm{B}, \mathrm{C} \\
\mathrm{E}<\mathrm{B}, \mathrm{C}\end{array}$} & & \\
\hline
\end{tabular}

As can be seen in Table 3, when the participants were examined according to age variable, the perception of health scale was not statistically significant in the control center sub-dimension and life satisfaction scale, and it was determined that this differences were caused by individuals between the ages of 29-32 and 33 and older individuals $(\mathrm{p}<0,05)$.

Table 5. Spearman Correlation Coefficient Results for Determining the Relationship Between Life Satisfaction Scale and Health Perception Scale Dimensions

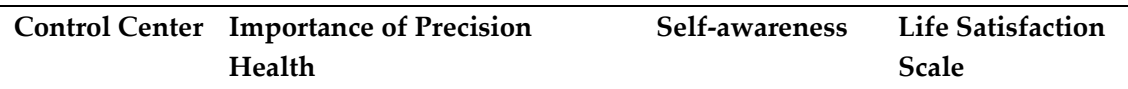

\begin{tabular}{|c|c|c|c|c|c|c|}
\hline \multirow{2}{*}{ Control Center } & $\mathrm{r}$ & \multirow{2}{*}{1} & & & & \\
\hline & $p$ & & & & & \\
\hline \multirow{2}{*}{ Importance of Health } & $\mathrm{r}$ & $0,505^{* *}$ & \multirow{2}{*}{1} & & & \\
\hline & $p$ & 0,000 & & & & \\
\hline \multirow{2}{*}{ Precision } & $\mathrm{r}$ & $0,497^{* *}$ & 0,446 & \multirow{2}{*}{1} & & \\
\hline & $\mathrm{p}$ & 0,000 & 0,000 & & & \\
\hline \multirow{2}{*}{ Self-awareness } & $\mathrm{r}$ & $0,543^{* *}$ & 0,405 & $0,676^{* *}$ & \multirow{2}{*}{1} & \\
\hline & $p$ & $0,000^{* *}$ & 0,000 & 0,000 & & \\
\hline \multirow{2}{*}{ Life Satisfaction Scale } & $\mathrm{r}$ & $0,185^{*}$ & $0,165^{*}$ & $0,142^{*}$ & $0,209^{* *}$ & \multirow{2}{*}{1} \\
\hline & $\mathrm{p}$ & 0,010 & 0,022 & 0,049 & 0,004 & \\
\hline
\end{tabular}

${ }^{{ }^{*} \mathrm{p}<0,05 ; * * p<0,01}$

The relationship between life satisfaction scale and health perception scale dimensions of recreational sports members of fitness centers were investigated. As a result of this study, a statistically significant relationship was found between the scale and the sub-dimensions.

There was a low positive correlation between life satisfaction scale and health perception scale importance of health sub-dimension $(r=0.152 ; \mathrm{p}<0.05)$.

\section{DISCUSSION}

Health awareness/perception and life satisfaction contexts which were handled when reasons of individuals do recreational workouts are considered as gains of individuals participating in recreational activities (3). When it is studied within this context, the main purpose of this study is to determine the current health perceptions and life satisfaction of individuals who benefit from fitness centers for
There was a low positive correlation between life satisfaction scale and health perception scale control center sub-dimension $(r=0,185 ; \mathrm{p}<0,05)$.

There was a low positive correlation between life satisfaction scale and health perception scale precision sub-dimension $(r=0,165 ; p<0,05)$.

There was a low positive correlation between life satisfaction scale and health perception scale selfawareness sub-dimension $(r=0,209 ; \mathrm{p}<0,01)$.

leisure time evaluation and to reveal the relationship between these two cases.

In our study, health perception and life satisfaction scale scores of male participants were higher than female participants according to gender. In his study, Ardahan (2) states that health is the most important factor motivating female individuals for recreational workout and that it is focused on competition and power for male individuals. Since the result in favor of male participants in the health 
perception precision sub-dimension expresses inadequate knowledge and inadequacy about being healthy, we can say that it is actually a result in favor of women and is compatible with the literature. The same situation is valid for the results of the sub-dimensions of the importance of health and the self-awareness sub-dimensions of health perception scale according to age variable. It is observed that the mean age decreases as age increases in the sub-dimensions. When the average age and education levels are taken into consideration, the development and increase of health education and awareness will increase the level of inclination to anti-social behaviors and subjective well-being and life level will be positively affected. In the descriptive study by Evren et al. (12) examining the relationship between student behaviors and perceived health; it was stated that health perception was affected by behaviors. In a descriptive study conducted with adolescents in Izmir by Simsek et al. (19), healthy lifestyle behaviors were examined and emphasized the importance of health. In another descriptive study by Kara et al. (15), conducted with adolescents, risky health behaviors were evaluated, and it was found that education was effective in health perception and importance. When results of intervention study conducted by Cevizci et al. (8) on disadvantaged by performing 3 weeks of supportive training are considered, it was seen that students' health perception improved at the end of the training. In the same study; benefits of health promotion intervention programs and health education with the participation of professionals from different disciplines are mentioned. In the research of Şengel (18), the importance of multidisciplinary studies in the development of health perception was highlighted and it was concluded that social responsibility and social harmony towards health can be adopted through sports and exercise in the effect pattern nature.

In the study of Evren et al., It can make inference in relation to life satisfaction and health perception that as the level of social acceptance increases, health perception increases as well, and life satisfaction level is affected. It is clear that new policies are needed in areas such as transportation, sports, entertainment and urban planning to make our young people more active (15). These policies should aim to make people use their bodies more in daily activities. For example, walking can be made a natural part of daily activities by arranging places such as homes, schools and neighborhoods.

\section{REFERENCES}

1. Açıkgöz S, Uzun Ş, Arslan F. Hemşirelik öğrencilerinin sağlık algısı ile sağlığı geliştirme davranışları arasındaki ilişkinin incelenmesi. Gülhane Askeri Tip Akademisi Dergisi, 2013.

2. Ardahan F. "Bireyleri Rekreatif Spor Etkinliklerine Motive Eden Faktörlerin Remm Ölçeğini Kullanarak Çeşitli Demografik Değişkenlere Göre İncelenmesi: Antalya Örneği ", Pamukkale Journal of Sport Sciences, vol.4, pp.1-15, 2013.

3. Ardahan F, Lapa Yerlisu T. Outdoor recreation: the reasons and carried benefits for attending outdoor sports of the participants of cycling and/or trekking activities International Journal of Human Sciences, 2010, 8 (1): 1327- 1341.

4. Aydın A. Fitnes Salonu Kullanan Bireylerin Fiziksel Aktivitelerine Etki Eden Faktörler (Yalova Örneği). Spor Eğitimi Dergisi, 2019.

5. Aydın Dinçer GB. Fizyoterapi Öğrencilerinin Sağlık Algısı ve Sağlıklı Yaşam Biçimi Davranışlarının İncelenmesi. Süleyman Demirel Üniversitesi Sağllk Bilimleri Enstitüsü Fizyoterapi ve Rehabilitasyon Anabilim Dalı. Yüksek Lisans Tezi, Isparta, 2019.

6. Bottorff JL, Johnson JL, Ratner PA, Hayduk LA. The effects of cognitive-perceptual factors on health promotion behavior maintenance. Nurs Res 1996; 45(1): 30-36.

7. Can U. 40 Yaş Üstü Erkeklerde 8 Haftalık Aerobik Çalışmalarının Bazı Fizyolojik ve Motorik Parametrelere Etkisinin Araştırılması., Yüksek Lisans Tezi, Muğla Üniversitesi, Muğla. 2009.

8. Cevizci S, Uludağ A, Babaoğlu ÜT, Karaahmet E, Vural A, Şahin EM, Özdemir H ve Ünver A. Dezavantajlı öğrencilerde sağllk algısının ve psikososyal becerilerin geliştirilmesi: Okul tabanlı bir müdahale çalışması. TAF Preventive Medicine Bulletin, 2015, 14(1), 39-48.

9. Diamond JJ, Becker JA, Arenson CA, Chambers CV, Rosenthal MP. Development of a scale to measure adults' perceptions of health: priliminary findings. Journal of Community Psychology 2007;35(5):557-61.

10. Diem E, McKay L. Health concerns of adolescent girls. Journal of Pediatric Nursing, 1995; 10(1): 19-27

11. Diener E, Emmons RA, Larsen RJ, Griffin S. The Satisfaction With Life Scale. Journal of Personality Assessment, 1985, 49, 71-75.

12. Evren H, Tokuç B, Ekuklu G. Trakya Üniversitesi öğrencilerinde şiddet davranışları ve algılanan sağlık ilişkisi. Trakya University Students Balkan Med J. 2011; 28: 380-384.

13. Ferrand A, Robinson L, Valette P. The intention-to-repurchase paradox: A case of the health and fitness industry. Journal of Sport Management, 2010.

14. Kadıŏlu H, Yıldız A. Sağlık Algısı ölçeği'nin Türkçe çevriminin geçerlilik ve güvenilirliği. Türkiye Klinikleri, 2012; 32:47-53.

15. Kara B, Hatun Ş, Aydoğan M, Babaoğlu K, Gökalp AS. Kocaeli ilindeki lise öğrencilerinde sağlık açısından riskli davranışların değerlendirilmesi. Çocuk Sağlığı ve Hastalıkları Dergisi. 2003: 30-37.

16. Köker S. Normal ve Sorunlu Ergenlerin Yaşam Doyumu Düzeylerinin Karşılaştırılması. Yayınlanmamış Yüksek Lisans Tezi. Ankara: A.Ü. Sosyal Bilimler Enstitüsü. 1991.

17. Kumartaşlı M, Atabaş EG. Spor Merkezi Fitness Salonunu Kullanan Bireylerin Beklentilerinin Değerlendirilmesi. International Journal of Science Culture and Sport. July 2014. 
18. Şengel A. Sağlığa Yönelik Sosyal Sorumluluk Programının Ergenlerin Sağlık Algısı, Özgeci Ve Empatik Becerilerine Etkisi. Marmara Üniversitesi, Sağlık Bilimleri Enstitüsü, Halk Sağlığı Hemşireliği Anabilimdalı. Yayınlanmış Yüksek Lisans Tezi.2016

19. Şimşek H, Öztoprak D, İkizoğlu E, Safaıl F. Tıp fakültesi öğrencilerinde sağlıklı yaşam biçimi davranışları ve ilişkili etmenler. DEÜ Tıp Fakültesi Dergisi, 2012; 26: 151-157.

20. Tasgin E , Öz ND , Üstün F , Özlü M . Investıgatıon of The Expectations From Sports And Sports Centers For Different Variables. Turk J Sport Exe. 2018; 20(3): 273-276. 